\section{"ALGUMAS COISAS NÃO SÃO MUITO VERDADEIRAS": CONSUMO MIDIÁTICO E RECEPÇÃO DA PUBLICIDADE TELEVISIVA NA INFÂNCIA}

\author{
"Some things are not very true": media consumption and \\ reception of television advertising in childhood \\ "Algunas cosas no son tan ciertas": consumo de medios y \\ recepción de la publicidad televisiva en la infancia
}

\author{
Fárida M. Rabuske Kuntz \\ Universidade Federal de Santa Maria, Rio Grande do Sul, Brasil. \\ Mestranda pelo Programa de Pós-Graduação em Comunicação da Universidade Federal de Santa Maria. \\ E-mail: faridarabuske@gmail.com
}

\section{Elisa Reinhardt Piedras}

Universidade Federal do Rio Grande do Sul, Rio Grande do Sul, Brasil.

Doutora em Comunicação. Professora do Programa de Pós-Graduação em Comunicação e Informação da Universidade Federal do Rio Grande do Sul.

E-mail: elisapiedras@gmail.com

RESUMO O objetivo deste trabalho é explorar os hábitos de consumo na televisão e a recepção da publicidade dirigida à criança. Após uma discussão teórica sobre publicidade, recepção e infância, operacionalizamos metodologicamente a noção de fluxo publicitário em pesquisa exploratória e qualitativa, realizada por meio de entrevistas com seis crianças. Os resultados revelam hábitos de consumo e práticas de recepção da publicidade televisiva.

PALAVRAS-CHAVE Publicidade, Fluxo Publicitário, Televisão, Recepção, Infância.

ABSTRACT This study aims to explore television consumption and reception of advertising addressed to children. After a theoretical discussion about advertising, reception and childhood, we methodologically implemented the concept of advertising flow in an exploratory and qualitative research conducted through interviews with six children. The results show consumption habits and reception practices of television advertising.

KEYWORDS Advertising, Advertising flow, Television, Reception, Childhood

RESUMEN El objetivo de este estudio es conocer los hábitos de consumo en televisión y la recepción de la publicidad dirigida a los niños. Después de una discusión teórica sobre publicidad, recepción e infancia, utilizamos metodológicamente el concepto de flujo publicitario en una investigación exploratoria y cualitativa, realizada por medio de entrevistas con seis niños. Los resultados demuestran hábitos de consumo y prácticas de la recepción de la publicidad televisiva.

PALABRAS CLAVE Publicidad, Flujo Publicitario, Televisión, Recepción, Infancia.

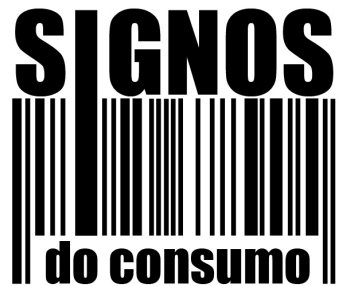

artigo 


\section{QUANDO SE TRATA DE PUBLICIDADE E INFÂNCIA}

A recente trajetória sociocultural da "criança" e da noção de "infância" é reconstituída por Ariès (1981), que esclarece como as "idades da vida" correspondem a funções sociais, para além de etapas biológicas. Após retomar historicamente a "descoberta da infância" a partir do século XIII, o autor explora seus sinais mais significativos nos séculos XVI e XVII, mediante o vestuário, jogos e brincadeiras, da vida escolar entre outros aspectos, destacando as transformações na família e na educação.

Essa construção social inclui alguns mitos, entre eles o da "criança feliz", desconstruído por Abramovich (1983a), que também se dedicou a discutir a produção cultural brasileira (literatura, música, teatro e televisão) dirigida à criança nos anos 1980. Segundo ela,

o verdadeiro reduto da criança da TV é no comercial [...] Lá está ela, posta no papel de grande consumidora destes tempos ou induzindo os adultos a comprarem toda sorte de coisas, façam ou não parte do mundo e das necessidades infantis [...] Crianças vivendo situações adultas - flertando, fazendo poses sexy, seduzindo, liderando massas, mostrando uma memória prodigiosa, comendo toda sorte de produtos alimentícios possíveis - num país que passa fome! - vestindo roupas de todo tipo de qualidade, comprando presentes para a mãe, avó, tia, professora, pai, avô, e qualquer familiar distante, fazendo chantagens afetivas, enfim, sendo usadas como vinculadoras de tudo e criando a necessidade de que comprem tudo. (Abramovich, 1983b, p. 133)

Já nos anos 1990, pesquisas realizadas no Laboratório de Pesquisas sobre Infância, Imaginário e Comunicação da Escola de Comunicações e Artes da Universidade de São Paulo apontavam indícios de recepção ativa por parte do público infantil, bem como a inexistência de uma relação de causa e efeito direta entre o que é exibido na televisão e o comportamento das crianças. Ao "desmistificar concepções apocalípticas e reducionistas sobre a relação TV/criança”, o Laboratório oportunizou o desenvolvimento de novos paradigmas teóricos e metodológicos para a compreensão da relação da criança com a mídia (Pacheco, 2000, p. 110).

No contexto dos 24 estudos de recepção da publicidade realizados em teses e dissertações no Brasil no período entre 1990 e 2010 (Jacks; Menezes; Piedras, 2008; Piedras, 2014), apenas duas contemplaram o público infantil: "A comunicação mercadológica trabalhando a motivação no consumo infantil" (Marin, 2000), de abordagem comportamental; e "As representações sociais do receptor infantil de duas escolas da cidade de São Paulo, a partir de comerciais de TV" (Yanaze, 2005), de abordagem sociocultural. Já no âmbito dos eventos científicos, o Grupo de Trabalho Publicidade e Propaganda do Congresso Brasileiro de Ciências da Comunicação (Intercom) promove esse debate. As pesquisas sobre publicidade e infância têm perspectivas diversas: predominam discussões teóricas realizadas via pesquisa bibliográfica (Baader, 2012; Bragaglia; Cabral; Seabra, 2011; Ferreira, 2015; Guedes, 2012; Ribeiro; Arruda, 2014) ou estudos empíricos desenvolvidos através da análise de conteúdo (Freitas, 2011, 2013; Franco et al., 2015; Jesus, 2013, 2014; Soares et al., 2013; Torres; Moreira; Tavares, 2015). Excepcionalmente, há casos de pesquisas observacionais que adotam entrevista com a criança e/ou seus pais (Borges et al., 2011; Jesus; Molina; Viola, 2015; Martins, 2015; Sá, 2011; Soares et al., 2011). 
Uma questão pouco problematizada nas pesquisas é a amplitude do conceito de infância, pois a criança é vista como um ser humano em desenvolvimento, que está sendo preparado para assumir plenamente "uma vida independente na sociedade", como decreta a Convenção das Nações Unidas sobre os Direitos da Criança (Brasil, 1990a). Nesse longo período etário, entre 0 e 12 anos, uma diversidade de fases norteia o desenvolvimento infantil, e nesse sentido trabalharam pesquisadores da área da psicologia inspirados por Freud e Piaget (Bee; Boyd, 2011; Papalia; Olds; Feldman, 2010).

Mas independente da idade, no Brasil assim como em outros países vigora o pressuposto da hipossuficiência infantil:

A criança, justamente por ser um ser em formação física, psicológica, emocional e social, pode ser considerada vulnerável em sua essência e, por isso, requer uma atenção diferenciada em seu tratamento, [...] a necessidade de uma proteção a mais para este indivíduo, além daquela conferida a todos os outros cidadãos. (Vasconcelos, 2010, p. 7)

Nesse sentido, os direitos da criança estão relacionados aos deveres da família, da sociedade e do Estado em relação a ela, segundo indicam a Constituição Federal brasileira e o Estatuto da Criança e do Adolescente.

$\mathrm{Na}$ área do direito, segundo pesquisadores e legisladores, a hipossuficiência é a qualidade atribuída à parte mais fraca em uma relação de mercado, enquanto a vulnerabilidade reflete a situação de todos os indivíduos, pois qualquer um pode ser lesado no consumo. Assim, na sociedade e especificamente no Direito do Consumidor, a criança é colocada na posição de um indivíduo a ser defendido. (Fernandes, 2010; Henriques, 2006)

A publicidade no Brasil é regulada por órgãos que visam a garantir sua compatibilidade com os valores sociais vigentes, mediante um sistema misto: privado (autorregulatório) e estatal (Poder Judiciário). No artigo 37, parágrafo II, alínea b, do Conselho Nacional de Autorregulamentação Publicitária (CONAR, 2010) orienta que a publicidade para criança é permitida se respeitar "a dignidade, ingenuidade, credulidade, inexperiência e o sentimento de lealdade do público-alvo”. Não há, entretanto, restrição de horários e programações para veiculação de anúncios voltados à criança, o que delega aos pais ou responsáveis o controle da exposição à publicidade. As práticas de produção dos publicitários e os anúncios também se submetem ao Código de Defesa do Consumidor, que aborda o consumo nas esferas civil, administrativa e penal, e define no artigo $2^{\circ}$ que o "consumidor é toda pessoa física ou jurídica que adquire ou utiliza produto ou serviço como destinatário final” (Brasil, 1990b), além de caracterizar publicidade enganosa ou abusiva.

Tratando-se do público infantil, segundo Henriques (2006), a publicidade pode causar efeitos negativos na formação da personalidade, do caráter, dos valores éticos, sociais, culturais e morais. Para ela, os anúncios podem gerar na criança inveja, ganância, gula, atitudes arriscadas ou perigosas, além do consumismo, trazendo tristezas e frustrações por motivos fúteis, como o de não possuir determinado produto. Por outro lado, Orofino $(2011$, p. 3) alerta para o fato de que a criança ainda é colocada "no lugar do outro inferior. [...] São raras as pesquisas que se interessam pela condição da criança enquanto receptor ativo, capaz de 'se defender', de escolher ou de ressignificar o 
que a mídia coloca em pauta”. Cabe pensar então o potencial existente na vulnerabilidade, destacado por Brown (2010, 2012), segundo a qual, ao aceitar essa condição, o indivíduo se exime de tentar controlar e prever tudo que ocorre a seu redor. Ser vulnerável corresponderia a agir com coragem, e não com fraqueza, e a "vulnerabilidade é o berço da inovação, criatividade e mudança” (Brown, 2012).

Nas ciências sociais, no âmbito internacional, a relação da criança com a mídia e o consumo é discutida em diversas áreas do conhecimento e dominada por posições antagônicas. Livingstone (2002), precursora na investigação crítica sobre o tema, recentemente se dedica a pensar "as crianças da era da internet”, coordenando a rede de pesquisa EU Kids Online. Buckingham (2007) contribui com a discussão sobre como é “crescer na era das mídias", e com ele dialoga a brasileira Orofino (2005), ao problematizar o papel da escola na relação das crianças com a mídia e o consumo. Segundo ela, no Brasil, "o número de horas em que as crianças e adolescentes passam diante das mídias (televisão e computador) [...] é sem dúvida superior ao tempo em que as crianças e adolescentes passam na escola.” (Orofino, 2005, p. 51) E nesse contexto midiático, “os conteúdos têm privilegiado aspectos da cultura consumista, classista, patriarcal, de etnia branca, heterossexual.” (Orofino 2005, p. 76-77). Segundo as estatísticas apresentadas pelo Instituto Alana (2009), no Brasil as crianças passam muito tempo diante da televisão, e o passeio favorito das famílias é no shopping center (Revista Galileu, 2011). Segundo o Instituto, 83\% das crianças brasileiras são influenciadas pela publicidade (Revista Galileu, 2011) e $80 \%$ da influência de compra dentro de uma casa vêm das crianças (Instituto Alana, 2009). Diante disso, alguns críticos condenam a mídia e propõem abolir a publicidade direcionada a crianças, enquanto outros são a favor de uma abordagem educativa, através da qual seja possível preparar para o consumo.

Com base em suas pesquisas, Buckingham (2007) afirma que dadas todas as incertezas e riscos que compõem o consumo na infância, talvez o poder do marketing sobre as crianças seja mais limitado do que costumamos acreditar: pode ser "bem difícil para os mercadólogos gerenciarem e controlarem os significados que as crianças produzem.” (Buckingham, 2012, p. 53). Para chegar a uma abordagem como esta, os estudos sobre como a criança entende, interpreta e avalia o que assiste ou lê, passaram do foco behaviorista para o construtivista (ou cognitivista). Portanto, "as crianças não são vistas aqui como receptores passivos das mensagens da mídia, mas como processadores ativos de significados. [...] Nessa perspectiva, o significado dos textos midiáticos não é apenas entregue ao público, mas construído por ele” (Buckingham, 2007, p. 155).

Visando contribuir nessa perspectiva, o objetivo desta pesquisa é explorar os hábitos de consumo de televisão e a recepção da publicidade dirigida à criança. Para isso, após uma breve discussão teórica sobre recepção da publicidade, operacionalizamos metodologicamente a noção de fluxo publicitário em uma pesquisa exploratória e qualitativa, realizada por meio de entrevistas com seis crianças (8-10 anos, classe AB, residentes em Porto Alegre, Rio Grande do Sul).

A escolha da televisão para constituir o objeto empírico dialoga com a ideia do "fluxo publicitário televisivo" e, além disso, se justifica pelo fato de este ser um meio muito presente no cotidiano brasileiro, como fonte de informação e lazer, inclusive como "babá virtual" (Henriques, 2006). A opção por pesquisar crianças na região Sul do país é uma questão de conveniência geográfica. Explorar o universo infantil no contexto 
socioeconômico relacionado à classe $\mathrm{AB}$ remete a um meio privilegiado de acesso à informação e educação, além de amparo familiar. Devido à necessidade de recorte para viabilização da pesquisa, ficamos restritos a este grupo, quando sem dúvida seria oportuno também investigar crianças da classe $C D$, o que pode ser feito futuramente. Por fim, a escolha por abordar crianças com idade entre 8 e 10 anos se justifica porque essas crianças estão em um estágio de pleno desenvolvimento social, possuindo noções de justiça, de julgamento moral e de sua própria personalidade. Nessa idade, elas já concluíram várias atividades educacionais e possuem um pensamento abstrato mais ou menos desenvolvido (Bee; Boyd, 2011), estando aptas a interagir de forma rica na pesquisa.

\section{QUESTÕES TEÓRICO-METODOLÓGICAS SOBRE A RECEPÇÃO DA PUBLICIDADE}

Ao pesquisar a recepção da publicidade, pensamos em sua faceta sociocultural, como uma narrativa do consumo, que vai muito além de um esforço de vendas com investimento em mídia. Em uma perspectiva norteada pela função comercial da publicidade, Gomes (2003) define a comunicação persuasiva como qualquer esforço no sentido de promover um produto (seja bem ou serviço) ou informar sobre ele. Rocha (2005) amplia esse olhar considerando que, se o consumo produz um código que traduz muitos aspectos da sociedade, a publicidade é a parte responsável por tornar este código público.

No processo de comunicação persuasiva, as práticas de produtores e receptores são articuladas mediante campanhas e anúncios, num fluxo publicitário (Piedras, 2009). Nosso olhar nesta pesquisa privilegia a "recepção", que segundo Jacks e Escosteguy (2005, p. 50), é “o processo de relação com os meios, o polo oposto ao da emissão, os receptores, o momento de interação ou até mesmo todos os aspectos, que estariam simultaneamente reunidos naquela mesma expressão". As práticas de recepção e apropriação dos anúncios são condicionadas por modos de ver, contextos e realidades do público. Disso resulta uma variedade de sentidos e usos, atravessados por hábitos de consumo dos meios e competências de leitura (Piedras, 2007).

Os anúncios no meio televisivo são explorados mediante a noção de fluxo televisivo (Williams, 1974), norteada pela observação das interrupções operadas pela publicidade como parte de uma sequência, e não como uma unidade excluída da programação televisiva. Por isso, tratamos os anúncios como um fluxo publicitário, ou um conjunto multiforme de anúncios (impressos, eletrônicos, interativos) e ações (brindes, marketing viral), que são disseminados em vários meios técnicos (massivos, alternativos, etc.) e suportes (de rua, de trânsito, etc.), num lugar específico e durante determinado tempo (Piedras, 2009).

Nessa perspectiva, para pensar a recepção da publicidade televisiva pela criança, antes precisamos explorar seus hábitos de consumo midiático, o que determina em parte essa "oferta” ou "exposição”. Ao estudar o consumo de mídia por crianças, Henriques (2010) constatou que aquelas que passam mais tempo sozinhas assistindo à televisão são menos críticas diante das mensagens, sendo ainda propensas a trocar a mídia pela convivência com família e amigos. Além disso, segundo a autora, as crianças latino-americanas não assistem apenas à programação infantil, mas sim àquela destinada a adultos (Henriques, 2010). Portanto, antes mesmo de ser alfabetizada, qualquer criança já está familiarizada 
com o enredo de desenhos televisivos e com os produtos comerciais divulgados na televisão. Em idade escolar, segundo a autora, o público infantil já consome diretamente, com sua mesada, alguns produtos que escolhe sozinho, com o aval da família (Henriques, 2006).

Especificamente quanto à capacidade da criança para discernir o conteúdo da publicidade, ou sua criticidade em relação à persuasão, há visões contraditórias: para Linn (2006), mesmo crianças com 8 anos não entendem o discurso persuasivo da publicidade e não a assistem com olhar crítico; Gade (1980) acredita que as crianças são incrédulas e "espertas"; e Buckingham (2007) afirma que este público é sim capaz de não tomar a televisão e a mídia como norma de comportamento. Entretanto, cabe lembrar a ressalva de Baudrillard na década de 1970, a respeito do "poder de condicionamento da publicidade (dos mass media em geral)”, sua lógica e sua eficácia:

Não mais se trata de uma lógica do enunciado e da prova, mas sim de uma lógica de fábula e adesão. Não acreditamos nela e todavia a mantemos. Não fundo a "demonstração" do produto não persuade ninguém: serve para racionalizar a compra que de qualquer maneira precede ou ultrapassa os motivos racionais. Todavia, sem 'crer' neste produto, creio na publicidade que quer me fazer crer nele. É a velha história do Papai Noel: as crianças não mais se interrogam sobre a sua existência e jamais a relacionam com os brinquedos que recebem como causa e efeito - a crença no Papai Noel é uma fabulação racionalizante que permite preservar na segunda infância a miraculosa relação de gratificação pelos pais (mais precisamente pela mãe) que caracterizara as relações da primeira infância (Baudrillard, 1973, p. 175-176, grifo no original).

Diante de um panorama teórico com diferentes visões, parece haver um consenso de que é preciso precaução quanto aos excessos de exposição à publicidade sem assistência de adultos, seja para preservar a infância em condição de hipossuficiência ou para promover maior criticidade no que se refere às mensagens midiáticas.

Para explorar no âmbito empírico os hábitos de consumo de televisão e a recepção da publicidade dirigida à criança, realizamos uma pesquisa exploratória e qualitativa, que "evita números e lida com interpretações das realidades sociais” (Bauer; Gaskell, 2007, p. 26), não indica incidências, mas sim significados (Flick, 2009). A técnica adotada na investigação é a entrevista (Duarte; Barros, 2009), realizada em dois encontros sucessivos, visando primeiro conhecer os hábitos de consumo midiático, para então identificar a publicidade a que as crianças estariam expostas, e enfim explorar sua recepção. A escolha da técnica permitiu uma preparação do pesquisador para o campo, com vistas a se aproximar ao máximo da situação cotidiana de recepção. Talvez a técnica da observação participante pudesse suprir a demanda (se realizada no horário de consumo televisivo da criança), entretanto não traria a segurança de certo planejamento oportunizado pela entrevista, podendo ainda ser vista como invasiva pela criança. As entrevistas foram viabilizadas através de contatos com os pais dos informantes, que leram e concordaram com o Termo de Consentimento Livre e Esclarecido.

Trabalhar na perspectiva da recepção privilegia o cotidiano do receptor e sua relação com a publicidade, fornecendo pistas para compreender os usos dessa comunicação e as competências de leitura que atuam na produção de sentido (Piedras, 2007). Para operacionalizar 
empiricamente a noção de "fluxo publicitário", optamos por não selecionar prévia e aleatoriamente um anúncio isolado para expor aos informantes. No primeiro encontro, a entrevista explorou os hábitos de consumo midiático no meio televisivo, identificando os canais, horários e programas a que os informantes assistem e como o fazem. Em um momento intermediário entre o primeiro e o segundo encontro, tomando como base os resultados da primeira entrevista, coletamos o "fluxo publicitário televisivo" dos canais, horários e programas que as crianças costumavam assistir diariamente. Arquivamos essa "programação" audiovisual televisiva dos programas assistidos, que incluía os anúncios publicitários em dispositivo móvel (tablet) para posterior exposição aos informantes. Assim, no segundo encontro para entrevista, exploramos a recepção propriamente dita da oferta midiática e publicitária a que cada criança naturalmente costuma se expor, replicando a experiência relatada mediante a programação arquivada e disponível para ser assistida no tablet. A entrevista iniciou com a exposição da "programação" coletada, incluindo os intervalos comerciais, ou o "fluxo publicitário televisivo" que faz parte do cotidiano da criança e então observamos sua produção de sentido sobre os anúncios. Após a coleta em dois encontros sucessivos com cada informante, os registros em áudio foram transcritos e analisados à luz da discussão teórica antecedente, que apresentamos a seguir.

\section{RECEPÇÃO DA PUBLICIDADE TELEVISIVA NO UNIVERSO INFANTIL}

No contexto das seis crianças participantes da pesquisa, os hábitos de consumo de televisão limitam-se ao tempo livre, sendo que elas preferem realizar outras atividades e, segundo afirmam, priorizam seus deveres escolares. No entanto, mesmo a televisão não sendo uma "prioridade" entre as opções de lazer, as crianças disseram que gostam de assisti-la, como haviam indicado Henriques $(2006,2013)$ e Linn (2006). Os motivos para a apreciação desse consumo midiático são variados (entretenimento, diversão, aprendizado), a exemplo do relato de um menino (10 anos): ele gosta de assistir "porque passam algumas coisas tipo sem sentido e estranhas, e porque às vezes algumas coisas são bem engraçadas e que às vezes me ensina as coisas” (Informante 4). Por outro lado, uma menina (9 anos) explicou que não gosta porque “não dá coisa legal” (Informante 3), ou seja, insatisfeita com a qualidade da produção.

Em geral, os hábitos de consumo de televisão das crianças concentramse em canais por assinatura, principalmente Nickelodeon e Cartoon Network (também foram citados Disney Channel, Disney XD, Gloob, Fox, Animal Planet, National Geographic e a Globo - televisão aberta). Quanto aos horários, as crianças assistem quando escolhem (desde que não seja turno escolar e haja permissão dos pais). Os produtos midiáticos consumidos são muito diversos, mas se destacam Bob Esponja (animação do Nickelodeon) e iCarly (seriado infanto-juvenil do Nickelodeon). Algumas crianças também veem Carrossel (novela infanto-juvenil do SBT), Hora de aventura, Apenas um show, Pokémon, Padrinhos Mágicos (todos animações do Cartoon Network), Futurama, Simpsons, (animações adultas da Fox), The Walking Dead (seriado adulto de suspense da Fox), Austin and Ally, Os Feiticeiros de Waverly Place (seriados infanto-juvenis do Disney Channel) e Sessão da tarde (filmes na Globo). 
Considerando esses momentos de consumo de televisão e questionadas se gostavam "dos intervalos comerciais", as crianças em geral disseram não gostar da "interrupção", relatando inclusive suas estratégias para "fugir" da publicidade: "gosto de ver os desenhos, aí eu troco [de canal]" (Informante 5, 10 anos). Isso revela, primeiramente, a plena capacidade das crianças pesquisadas para discernir a programação televisiva (desenhos) da publicidade, e num segundo momento a clareza sobre suas preferências e a competência para preservá-las durante seu consumo midiático. Então, mesmo para crianças, os hábitos de consumo são trajetos do receptor pelo tempo e espaço da programação, quando ele opta entre as ofertas e cria desvios no fluxo planejado pelos publicitários para "atingi-las" (Piedras, 2007, 2009).

Após a exposição de cada criança a uma reprodução do "fluxo publicitário televisivo" que usualmente consome, questionamos simplesmente o que lhes chamou atenção, se gostaram e por quê. Uma diversidade de apropriações daquele fluxo foi relatada, em uma situação empírica que ecoou a perspectiva dos estudos de recepção, interessados nas produções de sentido e usos que cada público faz da mídia (Jacks; Escosteguy, 2005). Cabe destacar, no entanto, que as crianças manifestaram interesse e apreciação por anúncios que exploravam o humor: uma menina (9 anos) disse ter gostado "porque algumas eu achei engraçadas” (Informante 1). Por outro lado, alguns relatos reiteraram a insatisfação com a programação interrompida pela publicidade, o que gera uma relação negativa com o gênero, que segundo algumas narrativas "não contribui” de forma alguma:

\section{[O que achou das propagandas?]}

Ah, mais ou menos. Geralmente eu fico trocando de canal quando tá dando comercial. Às vezes eu sou obrigado a ver os comerciais.

[Por quê?]

Porque não tem nada passando.

[Tu gosta de ver?]

Não.

[Por quê?]

Ah, não sei. Porque não falam nada, não tem moral. Só pra atrapalhar. (Informante 1, 9 anos)

Ainda, em narrativas de crianças que afirmaram não terem gostado de algumas peças publicitárias, emergiram questões de gênero: eram propagandas "meio de guri" (Informante 1, menina, 9 anos) ou "muito de menina" (Informante 6, menino, 10 anos).

Ao aprofundar o debate questionando o motivo pelo qual a publicidade faz essa "desagradável” interrupção na programação, as crianças não souberam explicar, mas manifestaram consciência sobre seu caráter comercial. A exceção foi um menino (10 anos) que afirmou que as interrupções acontecem "pra dar publicidade pros produtos e pra ajudar e também dar dinheiro pro canal e pra própria produtora" (Informante 4).

Exploramos então o conhecimento das crianças sobre a produção da publicidade e algumas delas revelaram uma compreensão apurada e crítica do tema, o que é compatível com o estágio do seu desenvolvimento (Bee; Boyd, 2011), mas ainda surpreende como dado empírico. Um menino (10 anos) disse que quem faz as propagandas são "os donos do produto querendo tirar alguma coisa” (Informante 4) e uma menina (9 anos) explicou: “A pessoa que faz os produtos são os fabricantes, mas daí depois 
as pessoas que fazem, o engenheiro daquela fábrica, falam com outra pessoa pra fazer aquele troço daí as pessoas filmam. As pessoas do canal veem e colocam” (Informante 3 ).

Além da clareza na visão sobre a publicidade, há uma boa contextualização da comunicação em relação ao marketing e às empresas anunciantes, e alguma desconfiança sobre os objetivos dessas narrativas.

Por fim, ao discutir a visão das crianças pesquisadas sobre a função da publicidade, emergiram tanto aspectos comerciais quanto socioculturais dessa narrativa do consumo, como propõe Rocha $(2005,2006)$. Algumas crianças tinham clareza sobre o papel de divulgação assumido pela comunicação persuasiva: os anúncios servem "pra dar publicidade pros produtos” (Informante 4). Isso às vezes se confundiu com um papel informativo: "[servem] pra saber as coisas, anunciar, pras pessoas saberem o que as pessoas podem usar” (Informante 3); “mostra o que vai passar, as coisas que tem pra vender e tal” (Informante 2). Outras crianças (ambas meninas, 9 anos) destacaram o forte vínculo entre publicidade e consumo: os anúncios servem "pra fazer as pessoas comprarem" (Informante 1) e para "ficar sabendo antes de ir na loja" (Informante 3).

Aproveitando a discussão espontânea da relação de publicidade e consumo, questionamos se as crianças já haviam consumido produtos anunciados no intervalo que assistiram. Nos relatos de duas crianças, tratava-se de produtos alimentícios (cujos anúncios são pouco representativos quantitativamente na programação consumida) e não de brinquedos, como suspeitávamos. Uma menina (Informante 1) citou uma bebida à base de soja e disse não ter gostado dela. Da mesma forma, um menino não ficou satisfeito com um biscoito: contou que quis consumi-lo "porque eu vi no shopping, aí eu pensei que fosse bom e não é” (Informante 5). Diante das narrativas de insatisfação, perguntamos se os produtos eram realmente como mostrava sua publicidade (assistida na entrevista): "Não! Aquilo é só um desenho" (Informante 1), "não totalmente. A forma e o recheio é. Só que só tem dois tipos, e lá mostra uns cinco" (Informante 5). Essas narrativas contradizem os apontamentos de Fernandes (2010) e Henriques (2006, 2010), Linn (2006), Schor (2009).

Prosseguimos explorando a relação das crianças com a publicidade questionando se o que as peças em geral apresentam é verdade. Todas disseram que não, conforme explicou um menino de 10 anos: "algumas coisas não são muito verdadeiras, por exemplo, o Nescau. Ficar rápido com o Nescau não dá, né. Não é uma pílula que tu toma e fica assim” (Informante 4). Essa competência de leitura das crianças em relação ao conteúdo da publicidade revela que este público pode sim ser incrédulo e crítico diante da mídia, sabendo diferenciar a realidade da fantasia, como indicaram Gade (1980) e Buckingham (2007). Entretanto, é preciso ressaltar que, para Baudrillard (1973), trata-se de uma capacidade de crítica restrita apenas à (in)veracidade das informações contidas na publicidade, que não dá conta da complexidade da questão. Afinal, segundo ele, a sedução operada pela publicidade não decorre da "lógica do enunciado e da prova”, mas de outra pautada pela "fábula e adesão”.

\section{CONSIDERAÇÕES FINAIS}

Diante desses dados, destacamos que para alcançar os objetivos propostos foi crucial o movimento de operacionalizar metodológica e empiricamente a noção de fluxo publicitário. Talvez nisso resida uma contribuição do trabalho para a pesquisa em recepção da publicidade. 
Mediante essa proposta, chegamos a resultados que permitem compreender os hábitos de consumo do meio televisivo das crianças e, nesse contexto midiático, observamos a recepção da publicidade ofertada na programação consumida. Apesar de as crianças afirmarem não gostar dos intervalos comerciais, os dados indicam o papel da publicidade como narrativa do consumo. Na visão das crianças pesquisadas, a publicidade é sinônimo de "interrupção" de sua experiência de consumo midiático televisivo "para vender alguma coisa”. Suas narrativas em relação a isso demonstram que, para elas, a comunicação publicitária é invasiva, desagradável e por isso evitada através de estratégias específicas.

Esses meninos e meninas com idade entre 8 e 10 anos apresentam diferenças na forma de compreender a natureza comercial da publicidade e estabelecer alguma criticidade em relação a isso. No entanto, ao tomar como premissa a noção da vulnerabilidade infantil, torna-se surpreendente a observação das sutilezas dessa hipossuficiência, as quais são amparadas pela presença da família e da escola no grupo pesquisado. Afinal, como disse um dos informantes, no universo da publicidade "algumas coisas não são muito verdadeiras", e essas crianças têm consciência disso. Mas nesta narrativa do consumo que segue a lógica da fábula, o questionamento sobre a veracidade não é sinônimo de falta de adesão. A vulnerabilidade nesse caso não é privilégio do público infantil, mas de todos os receptores que creem nos recursos de racionalização oferecidos pela linguagem publicitária.

Nas práticas de recepção da publicidade, as crianças estabeleceram trajetos específicos entre os tempos e espaços da programação, "fugiram" da publicidade trocando a emissora na hora do intervalo, por considerarem desagradável. Afinal, como algumas delas sabem bem, a produção da publicidade segue interesses e estratégias particulares, vinculadas ao marketing, aos produtos e ao consumo. Os anúncios, segundo elas, existem para divulgar os produtos e informar as pessoas. A forma como a publicidade faz isso, as crianças reconhecem, é apresentando um mundo que é "verdade", como elas comprovam com suas próprias experiências de consumo.

Esses relatos, contrapostos às questões teóricas apresentadas, distanciam-se dos olhares denuncistas e superprotetores da psicologia e do direito. Essa incursão empírica revela uma realidade que tem sintonia com as abordagens da recepção e as concepções das ciências sociais, que reconhecem o papel ativo do público, inclusive infantil, como um sujeito que não "recebe" sentidos, mas os constrói com autonomia relativa. Para além dos sentidos sobre os produtos anunciados, cabe em trabalhos futuros problematizar a recepção diante da "eficácia" da publicidade em apresentar de forma normativa e prescritiva alguns valores e modelos sociais. Afinal, no caso do público infantil, sujeitos em formação, presumimos a necessidade de um dever concreto da família, escola e sociedade para questionar esses padrões que emergem de práticas cotidianas aparentemente tão simples como assistir à televisão.

Quanto à produção de sentido sobre anúncios específicos, cabe reconhecer que a questão não rendeu os frutos esperados ao longo da pesquisa. Apesar do interesse, nas narrativas das crianças isso se restringiu a poucas situações, concentrando-se nas discussões sobre a relação entre a publicidade e os produtos por ela anunciados que eram de fato consumidos. As crianças pesquisadas consomem alguns dos 
produtos que foram encontrados nos intervalos comerciais que assistem, mas não há nenhuma indicação de que o consumo seja incentivado exclusivamente pelas peças publicitárias. Trata-se de uma constatação empírica da discussão de Rocha (2006) sobre o fato de que o consumo da publicidade pode ser muito maior do que o consumo de bens, pois geralmente o receptor não adquire os bens que lhe são ofertados na publicidade. Esses indícios inesperados sobre as práticas de consumo de bens das crianças apresentam uma complexidade que seria oportuna enfocar em pesquisas futuras.

Além de identificar questões como essa, que merecem outros estudos, esperamos ter contribuído também para a relação entre sociedade e mercado. Afinal, problematizar a recepção que as crianças fazem da publicidade pode trazer subsídios ao debate sobre a regulamentação da publicidade e as políticas de educação para a mídia. Apesar de sua reconhecida vulnerabilidade, o público infantil não é alienado e totalmente suscetível aos apelos comerciais, merecendo um conteúdo que além de persuasivo seja de qualidade e ético.

\section{REFERÊNCIAS}

ABRAMOVICH, F. O mito da infância feliz. São Paulo: Summus, 1983a. . O estranho mundo que se mostra às crianças. São Paulo: Summus, 1983b.

ARIĖS, P. História social da criança e da família. Rio de Janeiro: Guanabara, 1981.

BAADER, C. Eatertainment: alimentação ou diversão? A divertida expressividade de marcas e produtos no contexto contemporâneo do consumo alimentar infantil. In: CONGRESSO BRASILEIRO DE CIÊNCIAS DA COMUNICAČ̃̃O - INTERCOM, 35., 2012, Fortaleza. Anais... São Paulo: Intercom, 2012. Disponível em: <http://bit.ly/2o3civT>. Acesso em: 12 jun. 2016.

BAUDRILLARD, J. O sistema dos objetos. São Paulo: Perspectiva, 1973.

BAUER, M.; GASKELL, G. Pesquisa qualitativa com texto, imagem e som: um manual prático. Petrópolis: Vozes, 2007.

BEE, H.; BOYD, D. A criança em desenvolvimento. Porto Alegre: Artmed, 2011.

BORGES, A. R.; SOARES, S. A.; COELHO, A.; PERSILVA, D.; BORGES, F. R. F. A embalagem sedutora na gôndola do supermercado: uma mídia para atrair e aguçar o desejo de consumo nas crianças. In: CONGRESSO BRASILEIRO DE CIÊNCIAS DA COMUNICAÇÃO INTERCOM, 34., 2011, Recife. Anais... São Paulo: Intercom, 2011. Disponível em: <http://bit. ly/2mJEh3M>. Acesso em: 12 jun. 2016

BRAGAGLIA, A. P.; CABRAL, A.; SEABRA, I. A regulação da publicidade infantil: uma arena de debates entre as organizações sociais e do mercado. In: CONGRESSO BRASILEIRO DE CIÊNCIAS DA COMUNICAÇÃO - INTERCOM, 34., 2011, Recife. Anais... São Paulo: Intercom, 2011. Disponível em: <http://bit.ly/2nYVgik>. Acesso em: 12 jun. 2016.

BRASIL. Decreto n. 99.710, de 21 de novembro de 1990. Promulga a convenção das Nações Unidas sobre os Direitos da Criança. Diário Oficial [da] República Federativa do Brasil, Poder Executivo, Brasília, DF, 22 nov. 1990a.

. Lei n. 8.078, de 11 de setembro de 1990. Dispõe sobre a proteção do consumidor e dá outras providências. Diário Oficial [da] República Federativa do Brasil, Poder Executivo, Brasilia, DF, 12 set. 1990b.

BROWN, B. Listenin to shame. In: TEDxHouston. New York: TEDx, 2012. Disponível em: <http://bit.ly/P8qkHo>. Acesso em: 8 jun. 2016.

The power of vulnerability. In: TEDxHouston. New York: TEDx, 2010. Palestra. Disponível em: http://bit.ly/1IJtLD1. Acesso em: 8 jun. 2016.

BUCKINGHAM, D. Crescer na era das midias eletrônicas. São Paulo: Loyola, 2007. 
CONSELHO NACIONAL DE AUTORREGULAMENTAÇÃO PUBLICITÁRIA (CONAR). Código de Autorregulamentação Publicitária. 2010. Disponível em: <http://bit.ly/1zFJpGE>. Acesso em: 6 jul. 2016.

DUARTE, J.; BARROS, A. (Orgs.). Métodos e técnicas de pesquisa em comunicação. São Paulo: Atlas, 2009.

FERNANDES, M. M. A publicidade abusiva diante da hipossuficiência da criança: um estudo à luz do princípio da proteção integral. 66 f. 2010. Monografia (Bacharelado em Direito) - Universidade do Extremo Sul Catarinense, Criciúma, 2010.

FERREIRA, A. R. Publicidade infantil: impactos sobre o desenvolvimento da criança. In: CONGRESSO BRASILEIRO DE CIÊNCIAS DA COMUNICAÇÃO - INTERCOM, 38., 2015, Rio de Janeiro. Anais... São Paulo: Intercom, 2015. Disponível em: <http://bit.ly/2noifH8>. Acesso em: 12 jun. 2016.

FLICK, U. Desenho da pesquisa qualitativa. Porto Alegre: Artmed, 2009.

FRANCO, F. C. et al. Conteúdo de propaganda de alimentos destinado ao consumo infantil na rede de TV aberta em Vitória-ES. In: CONGRESSO BRASILEIRO DE CIÊNCIAS DA COMUNICAÇÃO - INTERCOM, 38., 2015, Rio de Janeiro. Anais... São Paulo: Intercom, 2015. Disponível em: <http://bit.ly/2mJDmA0>. Acesso em: 12 jun. 2016.

FREITAS, P. O. Criança e consumo: a publicidade em televisão para o dia das crianças. In: CONGRESSO BRASILEIRO DE CIÊNCIAS DA COMUNICAÇ̃̃O - INTERCOM, 34., 2011, Recife. Anais... São Paulo: Intercom, 2011. Disponível em: <http://bit.ly/2oabRNn>. Acesso em: 12 jun. 2016.

Relações de gênero: olhares para publicidade de brinquedos direcionada aos meninos. In: CONGRESSO BRASILEIRO DE CIÊNCIAS DA COMUNICAÇ̃̃O - INTERCOM, 36., 2013, Manaus. Anais... São Paulo: Intercom, 2013. Disponível em: <http://bit. ly/2nZ3gQt>. Acesso em: 12 jun. 2016.

GADE, C. Psicologia do Consumidor. São Paulo: EPU, 1980.

GOMES, N. D. Publicidade: comunicação persuasiva. Porto Alegre: Sulina, 2003.

GUEDES, B. L.. Relações de Gênero: Brincando de navegar: uma reflexão inicial sobre a emergente relação entre infância e mídia online. In: CONGRESSO BRASILEIRO DE CIÊNCIAS DA COMUNICAÇÃO - INTERCOM, 35., 2012, Fortaleza. Anais... São Paulo: Intercom, 2012. Disponível em: <http://bit.ly/2naKotP>. Acesso em: 12 jun. 2016.

HENRIQUES, I. V. M. Controle social e regulação da publicidade infantil. Revista Eletrônica de Comunicação, Informação e Inovação em Saúde, Rio de Janeiro, v. 4, n. 4, p. 72-84, nov., 2010. Disponível em: <http://bit.ly/2mJP9yy>. Acesso em: 10 abr. 2016.

Publicidade abusiva dirigida à criança. Curitiba: Juruá, 2006.

INSTITUTO ALANA. Crianças, a alma do negócio. 2009. Disponível em: <http://bit. ly/2orM42f>. Acesso em: 27 jun. 2016

JACKS, N. (Coord.); MENEZES, D.; PIEDRAS, E. R. Meios e audiências: a emergência dos estudos de recepção no Brasil. Porto Alegre: Sulina, 2008.

JACKS, N.; ESCOSTEGUY, A. C. Comunicação e recepção. São Paulo: Hacker, 2005.

JESUS, P. R. C. De pai para filho: a presença dos filhos de celebridades na propaganda de medicamentos. In: CONGRESSO BRASILEIRO DE CIÊNCIAS DA COMUNICAÇÃO - INTERCOM, 37., 2014, Foz do Iguaçu. Anais... São Paulo: Intercom, 2014. Disponível em: <http:// bit.ly/2nacCUR>. Acesso em: 12 jun. 2016.

O consumidor do futuro e as estratégias persuasivas: a utilização da criança nos anúncios publicitários no Brasil. In: CONGRESSO BRASILEIRO DE CIÊNCIAS DA COMUNICAÇÃO - INTERCOM, 36., 2013, Manaus. Anais... São Paulo: Intercom, 2013. Disponível em: <http://bit.ly/2mJSr4X>. Acesso em: 12 jun. 2016.

JESUS, P. R. C.; MOLINA, V. A. F.; VIOLA, A. L. N. M. Publicidade e consumo infantil: reflexões a partir da análise do filme publicitário Baton Musical Não e do comportamento das mães. In: CONGRESSO BRASILEIRO DE CIÊNCIAS DA COMUNICACC̃̃O - INTERCOM, 38., 2015, Rio de Janeiro. Anais... São Paulo: Intercom, 2015. Disponível em: <http://bit.ly/2oad$\mathrm{nPw}>$. Acesso em: 12 jun. 2016.

LINN, S. Crianças do consumo: a infância roubada. São Paulo: Instituto Alana, 2006. 
LIVINGSTONE, S. Young People and new media: childhood and the changing media environment. London: Sage, 2002.

MARIN, S. S. A comunicação mercadológica trabalhando a motivação no consumo infantil. 2000. Tese (Doutorado em Comunicação Social) - Universidade Metodista de São Paulo, São Bernardo do Campo, 2000.

MARTINS, I. S. S. A criança como influenciadora de compra: fatores de estímulo e a participação da publicidade neste comportamento. In: CONGRESSO BRASILEIRO DE CIÊNCIAS DA COMUNICAÇ̃̃O - INTERCOM, 38., 2015, Rio de Janeiro. Anais... São Paulo: Intercom, 2015. Disponível em: <http://bit.ly/2mJQkOM>. Acesso em: 12 jun. 2016.

OROFINO, M. I. Crianças, recepção e imaginários do consumo. In: ENCONTRO ANUAL DA COMPÓS, 20., 2011. Porto Alegre. Anais... Porto Alegre: FABICO-UFRGS, 2011.

. Mídias e mediação escolar: pedagogia dos meios, participação e visibilidade. São Paulo: Cortez, 2005.

PACHECO, E. D. LAPIC: Espaço lúdico de conhecimento sobre TV/Criança. Revista Comunicação \& Educação, São Paulo, n. 19, p. 107-115, set./dez. 2000. Disponível em: <http://bit. ly/2nZg74R>. Acesso em: 6 jul. 2016.

PAPALIA, D. E.; OLDS, S. W.; FELDMAN, R. D. O desenvolvimento humano. Porto Alegre: AMGH, 2010.

PIEDRAS, E. R. Ascensão dos estudos de recepção de publicidade: contribuições nas abordagens comportamental, sociocultural e sociodiscursiva. In: JACKS, N. (Org.). Meios e audiências Il: a consolidação dos estudos de recepção no Brasil. Porto Alegre: Sulina, 2014.

. Publicidade, imaginário e consumo: anúncios no cotidiano feminino. 227 f. 2007.

Tese (Doutorado em Comunicação Social) - Pontifícia Universidade Católica do Rio Grande do Sul, Porto Alegre, 2007.

. Fluxo publicitário: anúncios, produtores e receptores. Porto Alegre: Sulina, 2009.

REVISTA GALILEU. Animação: publicidade pega pesado com as crianças. 2011. Disponível em: <http://bit.ly/2orANiv>. Acesso em: 17 jun. 2016.

RIBEIRO, M. M. S.; ARRUDA, A. S. Publicidade x obesidade infantil: a guerra entre o capital e a saúde humana. In: CONGRESSO BRASILEIRO DE CIÊNCIAS DA COMUNICAÇÃO INTERCOM, 37., 2014, Foz do Iguaçu. Anais... São Paulo: Intercom, 2014. Disponível em: <http://bit.ly/2nFAbZF>. Acesso em: 12 jun. 2016.

ROCHA, E. Culpa e prazer: imagens do consumo na cultura de massa. Revista Comunicação, Mídia e Consumo, São Paulo, v. 2, n. 3, p. 123-138, 2005.

Representações do consumo: estudos sobre a narrativa publicitária. Rio de Janeiro: PUC-Rio; Mauad, 2006

SÁ, A. S. Consumo de moda do público infantil: o comportamento da nova geração. In: CONGRESSO BRASILEIRO DE CIÊNCIAS DA COMUNICAČÃO - INTERCOM, 34., 2011, Recife. Anais... São Paulo: Intercom, 2011. Disponível em: <http://bit.ly/2o3ysho>. Acesso em: 12 jun. 2016.

SCHOR, J. Nascidos para comprar: uma leitura essencial para orientarmos nossas crianças na era do consumismo. São Paulo: Gente, 2009.

SOARES, S. A.; BORGES, A. R.; KOIKE, A.; ALMEIRA, K. A força da publicidade infantil: composto de marketing e as embalagens dos produtos alimentícios da Turma da Mônica. In: CONGRESSO BRASILEIRO DE CIÊNCIAS DA COMUNICAÇÃO - INTERCOM, 36., 2013, Manaus. Anais... São Paulo: Intercom, 2013. Disponível em: <http://bit.ly/2orv7oL>. Acesso em: 12 jun. 2016.

SOARES, S. A.; BORGES, A. R.; PERSILVA, D.; COELHO, A. A persuasão da comunicação publicitária para o público infantil a partir das embalagens de produtos alimentícios. In: CONGRESSO BRASILEIRO DE CIÊNCIAS DA COMUNICAÇÃO - INTERCOM, 34., 2011, Recife. Anais... São Paulo: Intercom, 2011. Disponível em: <http://bit.ly/2ntCl8N>. Acesso em: 12 jun. 2016.

TORRES, G.; MOREIRA, L.; TAVARES, F. Consumo, identidade e obesidade infantil: como a publicidade produz o imaginário da criança no mercado brasileiro. In: CONGRESSO BRASILEIRO DE CIÊNCIAS DA COMUNICAÇÃO - INTERCOM, 38., 2015, Rio de Janeiro. Anais... São Paulo: Intercom, 2015. Disponível em: <http://bit.ly/2nZkr40>. Acesso em: 12 jun. 2016. 
VASCONCELOS, A. O controle da publicidade de alimentos não saudáveis dirigidos às crianças: autocontrole ou sistema misto? In: VIRVATA, V. (Coord.) Infância e consumo: estudos no campo da comunicação. Brasília, DF: ANDI; São Paulo: Instituto Alana, 2010.

WILLIAMS, R. Communications [Notas tomadas da tradução espanhola: Los Medios de Comunicación Social. Barcelona: Península, 1974]. London: Chatto e Windus, 1966.

YANAZE, L. As representações sociais do receptor infantil de duas escolas da cidade de São Paulo, a partir de comerciais de TV. São Paulo, 2005. Tese (Doutorado em Ciências da Comunicação) - Universidade Estadual de São Paulo, São Paulo, 2005. 